\title{
OGG1 wt Allele
}

National Cancer Institute

\section{Source}

National Cancer Institute. OGG1 wt Allele. NCI Thesaurus. Code C51000.

Human OGG1 wild-type allele is located in the vicinity of 3p26.2 and is approximately 18 $\mathrm{kb}$ in length. This allele, which encodes N-glycosylase/DNA lyase protein, plays a role in base excision repair. Defects in the OGG1 gene are associated with tumor formation. 